\title{
Pemanfaatan Website WWW.Pulokambing.Com Sebagai Media Rumah Kreatif Bersatu Nusantara (RKBN) Pulokambing Dalam Pemberdayaan Masyarakat
}

\author{
Saktisyahputra a,1, \\ ${ }^{a}$ Fakultas Ilmu Sosial dan Manajemen, Prodi Manajemen Komunikasi Institut Ilmu Sosial dan Manajemen STIAMI \\ ${ }^{1}$ Saktinabil@gmail.com
}

Keywords

Utilization

Website

Home

Creative

United

Nusantara

Pulokambing
Along with the development of information technology which is now increasingly rapid, thus changing the way humans human ways of conveying information. At present various information has used internet media as a supporting medium between humans and other humans. Following these developments, Pulokambing Archipelago United Creative House (RKBN) also utilizes by changing the promotion system and conventional community empowerment system using a website as a promotional medium in empowering the community to disseminate information about the Non Governmental Organization (NG) which aims to promote its products and services. By carrying out the Public Relations strategy in managing the website, This NGO hopes that there will be progress in terms of promotion and community empowerment. The purpose of this study is to determine the utilization and strategies used by Public Relations to increase the number of website visitors. The object in this study is the website www.pulokambing.com with a research approach using (IMC) Integrated Marketing Communication Theory, Qualitative case study methods, constructivist paradigms, while for data collection techniques using interviews, observation and documentation.The results of the study indicate that the use of the www.pulokambing.com website as a promotional medium in introducing products and services online. And improve the image of the NGO. In addition, community empowerment programs at Pulokambing RKBN such as the Unified KSPSS Cooperative in Pulokambing relatives, Pulokambing kinship farmers (PKPK), Waste Bank Management and Pulokambing Education Tourism strengthen the Website www.pulokambing.com.

\section{PENDAHULUAN}

Perkembangan teknologi informasi yang sangat pesat di era globalisasi saat ini telah memberikan banyak manfaat dalam kemajuan di berbagai aspek sosial. Penggunaan teknologi informasi oleh manusia dalam membantu melakukan aktivitas merupakan hal yang menjadi keharusan dalam kehidupan, dengan semakin berkembangnya teknologi informasi menunjukkan kemajuan yang sangat pesat. Perkembangan teknologi informasi yang begitu pesatnya ini telah memberikan manfaat yang sangat luar biasa bagi peradaban umat manusia. Adapun faktor yang memicu perkembangan teknologi adalah kebutuhan manusia akan teknologi dan informasi yang semakin pesat, sehingga menyentuh banyak pengguna dalam mengakses informasi dimanapun dan kapanpun.

Pemanfaatan internet saat ini sudah digunakan secara luas sebagai sarana pertukaran informasi. Perkembangan pengguna internet di Indonesia pada tahun 2017 sudah mencapai 143,26 juta orang. Berdasarkan hasil survei dari jenis kelamin, komposisi pengguna internet di Indonesia adalah $51,43 \%$ laki-laki dan 48,57\% perempuan. Adapun berdasarkan usia, sebanyak 16,68\% pengguna berusia 13-18 tahun dan 49,52\% berusia 19-34 tahun. Sementara itu, persentase pengguna internet berusia 35-54 tahun mencapai 29,55\%. Pengguna internet berusia 54 tahun ke atas mencapai $4,24 \%$. Sementara itu berdasarkan wilayah, lebih dari separuh atau $58.08 \%$ pengguna internet di Indonesia pada tahun 2017 berada di kota-kota besar di Pulau Jawa. Adapun untuk wilayah lainnya di luar dari kota besar yang disebutkan di atas, sekitar 19\% berada di Sumatera, 7,97\% di 
Kalimantan 5,63\% berada di Bali dan Nusa Tenggara 6,73\% berada di Sulawesi, serta 2,49\% di Maluku dan Papua. Rata-rata data perilaku pengguna internet di Indonesia. Berdasarkan konten yang paling sering dikunjungi, pengguna internet paling sering mengunjungi website yang menampilkan jasa jual-beli produk mencapai $62 \%$, bisnis professional/personal branding berada di angka 34,2\% serta konten lainnya sebanyak 3,8\% (http://www.apjii.or.id). Di dalam internet berbagai fasilitas tersedia dalam bentuk tulisan, gambar, video ataupun file multimedia yang bisa diakses oleh siapapun di seluruh dunia melalui internet. Umumnya penggunaan internet digunakan untuk mencari informasi yang dibutuhkan oleh manusia, dan untuk saat ini, internet tidak hanya berguna pada pencairan informasi saja, namun digunakan pula sebagai kegiatan promosi dalam memperkenalkan produk atau jasa baik individu maupun lembaga organisasi atau perusahaan, dari kegiatan promosi tersebut, akan ditampilkan beberapa produk atau jasa yang sebelumnya tidak dikenal menjadi dikenal karena dipublikasikan melalui internet. Pengguna internet semakin hari semakin bertambah, ini pula yang dimanfaatkan oleh banyak orang untuk memasarkan produk atau jasa kepada calon konsumen, pemasaran produk atau jasa melalui internet biasa disebut dengan $E$ marketing, dimana dulu kegiatan internet. Salah satu alasan bisnis atau pribadi membeli barang atau jasa melalui internet adalah karena kemudahan dalam memesan produk barang atau jasa yang bisa diakses di mana saja dan pada waktu kapan saja, di sini terlihat bahwa begitu pentingnya pemanfaatan internet terutama untuk mendapatkan comparative advantage. Hal ini dikarenakan fungsi dari internet dapat dijadikan sebagai sarana promosi dan pemasaran untuk memperluas jangkauan pasar. Dengan fungsi yang ada, sebuah perusahaan dapat mengoptimalkan penggunaan internet dalam mendukung kegiatan proses pemasaran yaitu dengan website perusahaan. Menurut Gregorius (dalam Priansa, 2017 : 178). Website adalah kumpulan halaman web yang saling terhubung dan file saling terkait. Web terdiri dari page atau halaman, dan kumpulan halaman yang dinamakan homepage. Homepage berada pada posisi teratas, dengan halaman-halaman terkait berada di bawahnya. Biasanya setiap halaman di bawah homepage ke halaman lain dalam web.

Rumah Kreatif Bersatu Nusantara (RKBN) Pulokambing adalah salah satu Lembaga Swadaya Masyarakat (LSM) yang memanfaatkan website sebagai media promosi untuk memasarkan produk dan jasa berupa branding product yang ingin diperkenalkan kepada pengguna jasa yang dikelola oleh bagian Public Relations dari RKBN Pulokambing. Adapun salah satu pemanfaatan teknologi informasi oleh LSM RKBN Pulokambing adalah menggunakan website www.pulokambing.com. Diharapkan website LSM RKBN Pulokambing mampu memberikan kemudahan bagi pengguna jasa yang ingin memperoleh informasi tentang LSM RKBN Pulokambing secara penuh, baik dari produk yang ditawarkan di dalam website, maupun layanan jasa yang terdapat di dalam website.

\section{LANDASAN TEORI}

Dalam penelitian ini penulis menggunakan teori Integrated Marketing Communication (IMC) atau yang biasa disebut dengan komunikasi pemasaran terpadu, teori ini pertama kali dicetuskan oleh Theodore Levitt pria kebangsaan Amerika, lahir di Jerman yang juga merupakan professor dalam bidang ekonomi di Harvard Business Scholl. Integrated Marketing Communication (IMC) merupakan salah satu strategi perusahaan untuk mengkomunikasikan produk secara efektif kepada pelanggan (Priansa, 2017 : 93). Konsep IMC menurut Schultz (dalam Priansa, 2017 : 100), merupakan sebuah strategi dalam proses bisnis dengan membuat perencanaan, membangun, mengeksekusi dan mengevaluasi pelaksanaan program komunikasi merek yang terkoordinasi pada konsumen, pelanggan atau sasaran lain yang relevan dengan audience eksternal dan internal.

\section{METODE PENELITIAN}

Metode yang digunakan dalam penelitian ini adalah metode kualitatif - interpretif dengan menggunakan studi kasus. Esensi tujuan penelitian ini adalah melakukan pemahaman (understanding) terhadap subyek yang diteliti melalui studi komparatif dengan menggunakan tiga variabel yaitu structure, conduct dan performance.Selain itu Menurut Bogdan dan Taylor (Moleong, 2000:3) merupakan prosedur penelitian yang menghasilkan data deskriptif berupa katakata tertulis atau lisan dari orang-orang dan perilaku yang dapat diamati. Dengan kata lain, pendekatan ini diarahkan pada data kata dan individu tersebut secara utuh. Dengan demikian, tidak 
mengisolasikan individu atau organisasi kedalam variabel atau hipotesis tetapi perlu memandangnya sebagai bagian dari suatu keutuhan.

Adapun metode yang digunakan dalam penelitian ini adalah studi kasus, menguraikan dan menjelaskan komprehensif mengenai berbagai aspek seseorang, individu, suatu kelompok, suatu organisasi (komunitas), suatu program atau suatu situasi sosial. Studi kasus memiliki batas, lingkup kajian dan pola pikir tersendiri; sehingga dapat mengungkapkan realitas sosial atau fisik yang unik, spesifik serta menantang. Studi kasus banyak mengungkapkan hal-hal yang amat detail, melihat hal-hal apa yang tidak bisa diungkapkan oleh metode lain, dan dapat menangkap makna yang ada di belakang kasus dalam kondisi objek secara natural (Salim, 2006:100).

Susilo Rahardjo \& Gudnanto (2011 : 250) studi kasus adalah suatu metode untuk memahami individu yang dilakukan secara integratif dan komprehensif agar diperoleh pemahaman yang mendalam tentang individu tersebut beserta masalah yang dihadapinya dengan tujuan masalahnya dapat terselesaikan dan memperoleh perkembangan diri yang baik.

Penelitian studi kasus berupaya menelaah sebanyak mungkin data mengenai subjek yang diteliti. Mereka sering menggunakan berbagai metode wawancara, pengamatan, penelaahan dokumen (hasil), survei, dan data apa pun untuk menguraikan suatu kasus secara terinci. Adapun metode yang digunakan dalam penelitian ini adalah studi kasus, menguraikan dan menjelaskan komprehensif mengenai berbagai aspek seseorang, individu, suatu kelompok, suatu organisasi (komunitas), suatu program atau suatu situasi sosial. Penelitian studi kasus berupaya menelaah sebanyak mungkin data mengenai subjek yang diteliti. Karena itu berdasarkan judul penelitian yang telah dipilih, maka penelitian ini akan berusaha memberikan gambaran mengenai Pemanfaatan Website www.pulokambing.com sebagai Media Rumah Kreatif Bersatu Nusantara (RKBN) Pulokambing dalam Pemberdayaan Masyarakat.

\subsection{Objek dan Subjek Penelitian}

Objek yang dijadikan informan dalam penelitian ini adalah Ketua LSM RKBN Pulokambing. Jumlah informan keseluruhan adalah satu orang Semua informan ini dilihat dapat mewakili apa yang ingin diteliti serta semuanya dipilih berdasarkan pada konteks yang peneliti ingin bahas dalam penelitian ini. Sedangkan subjek penelitian ini adalah informasi dari Website sebagai Media Rumah Kreatif Bersatu Nusantara (RKBN) Pulokambing dalam Pemberdayaan Masyarakat.

\subsection{Teknik Pengumpulan dan Pengolahan Data}

Teknik pengumpulan data dalam penelitian ini dilakukan dengan beberapa metode yaitu: 1 . Wawancara Mendalam Menurut Harsono, wawancara merupakan proses pengumpulan data yang langsung memperoleh informasi langsung dari sumbernya. Menurut Mantja (dalam Harsono, 2008: 162), wawancara mendalam merupakan percakapan terarah yang tujuannnya untuk mengumpulkan informasi etnografi. 2. Observasi Teknik pengumpulan data ini digunakan untuk menjaring data yang diperlukan guna melengkapi data dari wawancara. Menurut Sutopo (dalam Harsono, 2008: 164), observasi merupakan kegiatan pengamatan yang dilakukan oleh peneliti, di mana peneliti berperan aktif dalam lokasi studi sehingga benar-benar terlihat dalam kegiatan yang ditelitinya. 3 . Dokumentasi Dokumentasi adalah pengambilan data yang diproses melalui dokumen-dokumen. Metode dokumentasi dipakai untuk mengumpulkan data dari sumber-sumber dokumen yang mungkin mendukung atau bahkan berlawanan dengan hasil wawancara (Harsono, 2008: 165).

Penelitian kualitatif mengandalkan kecermatan pengumpulan data untuk memperoleh hasil penelitian yang valid.Adapun teknik pengumpulan data dalam penelitian ini adalah:

1. Data primer, yaitu diperoleh melalui sumber dimana biasanya dilakukan dalam dua cara yakni:

a. Observasi

Penulis mengadakan pengamatan langsung terhadap objek penelitian.

b. Indepth Interview (Wawancara Mendalam)

Penulis melakukan wawancara mendalam secara langsung dengan pihak yang dianggap dapat memberikan informasi (informan) dan berkompeten sesuai dengan permasalahan dalam penelitian. 
2. Data sekunder, yaitu data yang diperoleh melalui studi pustaka denganmembaca literatur, buku-buku bacaan dan tulisan ilmiah yang berkaitandan relevan dengan objek penelitian yang akan diteliti.

\subsection{Teknik Analisis Data}

Teknik analisis data dalam penelitian ini menggunakan Miles dan Huberman (Emzir 2010 : 13) menyatakan bahwa terdapat tiga macam kegiatan analisis data kualitatif, yaitu:

1. Reduksi Data

Data yang diperoleh di lapangan jumlahnya cukup banyak, untuk itu perlu dicatat secara teliti dan rinci. Mereduksi data berarti : merangkum, memilih hal-hal yang pokok, memfokuskan pada hal-hal yang penting, dicari tema dan polanya dan membuang yang tidak perlu. Data yang telah direduksi akan memberikan gambaran yang jelas dan mempermudah peneliti untuk melakukan pengumpulan data selanjutnya, dan mencarinya bila diperlukan.

Reduksi data bisa dibantu dengan alat elektronik seperti : komputer, dengan memberikan kode pada aspek-aspek tertentu. Dengan reduksi, maka peneliti merangkum, mengambil data yang penting, membuat kategorisasi, berdasarkan huruf besar, huruf kecil dan angka. Data yang tidak penting dibuang.

2. Model Data (Data Display)

Setelah data direduksi, maka langkah berikutnya adalah mendisplaykan data.Display data dalam penelitian kualitatif bisa dilakukan dalam bentuk : uraian singkat, bagan, hubungan antar kategori, flowchart dan sebagainya. Miles dan Huberman (1984) menyatakan : "the most frequent form of display data for qualitative research data in the pas has been narative tex" artinya : yang paling sering digunakan untuk menyajikan data dalam penelitian kualitatif dengan teks yang bersifat naratif. Selain dalam bentuk naratif, display data dapat juga berupa grafik, matriks, network (jejaring kerja).

Fenomena sosial bersifat kompleks, dan dinamis sehingga apa yang ditemukan saat memasuki lapangan dan setelah berlangsung agak lama di lapangan akan mengalami perkembangan data. Peneliti harus selalu menguji apa yang telah ditemukan pada saat memasuki lapangan yang masih bersifat hipotetik itu berkembang atau tidak. Bila setelah lama memasuki lapangan ternyata hipotesis yang dirumuskan selalu didukung data pada saat dikumpulkan di lapangan, maka hipotesis tersebut terbukti dan akan berkembang menjadi teori yang grounded. Teori grounded adalah teori yang ditemukan secara induktif, berdasarkan datadata yang ditemukan di lapangan, dan selanjutnya diuji melalui pengumpulan data yang terus menerus. Bila pola-pola yang ditemukan telah didukung oleh data selama penelitian, maka pola tersebut menjadi pola yang baku yang tidak lagi berubah. Pola tersebut selanjutnya didisplaykan pada laporan akhir penelitian.

3. Penarikan/Verifikasi Kesimpulan

Langkah ketiga adalah penarikan kesimpulan dan verifikasi. Kesimpulan awal yang dikemukakan masih bersifat sementara, dan akan berubah bila tidak ditemukan bukti-bukti yang kuat yang mendukung pada tahap pengumpulan data berikutnya. Namun bila kesimpulan memang telah didukung oleh bukti-bukti yang valid dan konsisten saat peneliti kembali ke lapangan mengumpulkan data, maka kesimpulan yang dikemukakan merupakan kesimpulan yang kredibel (dapat dipercaya).

Kesimpulan dalam penelitian kualitatif mungkin dapat menjawab rumusan masalah yang dirumuskan sejak awal, tetapi mungkin juga tidak, karena masalah dan rumusan masalah dalam penelitian kualitatif masih bersifat sementara dan akan berkembang setelah penelitian berada di lapangan. Kesimpulan dalam penelitian kualitatif yang diharapkan adalah merupakan temuan baru yang sebelumnya belum pernah ada. Temuan dapat berupa deskripsi atau gambaran suatu obyek yang sebelumnya masih belum jelas, sehingga setelah diteliti menjadi jelas. 


\section{PEMBAHASAN}

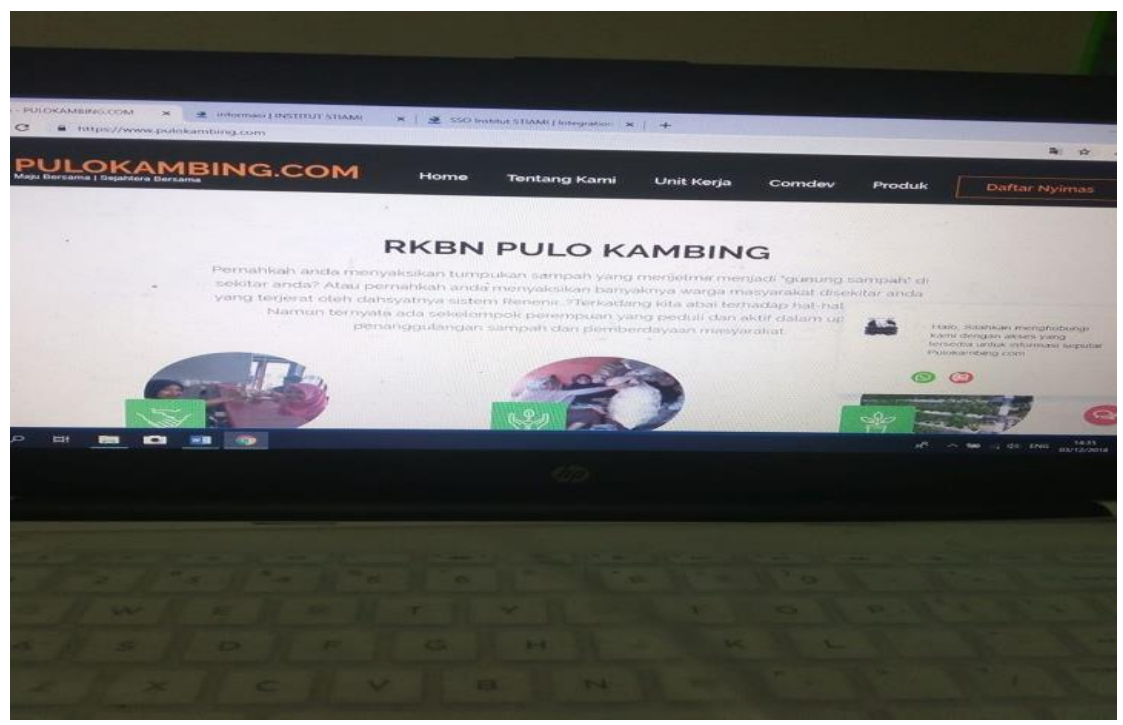

(Foto Halaman Depan Website)

Peneliti mewawancarai Key Informan terkait dengan Pemanfaatan Website www.pulokambing.com sebagai Media Rumah Kreatif Bersatu Nusantara (RKBN) Pulokambing dalam Pemberdayaan Masyarakat dengan Bu Vera Nofia sebagai Ketua LSM RKBN Pulokambing mengatakan bahwa :

“...Pemanfaatan Website sangat penting. Karena semua kegiatan LSM RKBN Pulokambing saya update di sana...” (Sabtu, 1 Desember 2018)

Perumusan dalam menampilkan konten menjadi cara yang perlu diperhatikan menjadi cara yang perlu diperhatikan dalam website LSM, dimana web mampu memberikan informasi kepada pengunjung website untuk mengetahui informasi apa saja yang bisa mereka temukan dalam web web yang sesuai dengan kebutuhan informasi yang mereka cari, mengenai isi konten yang terdapat, penulis melakukan wawancara dengan Ketua LSM RKBN Pulokambing, Bu Vera mengatakan bahwa :

“....Konten dalam website sangat penting terutama informasi-informasi program kami seperti pengelolaan bank sampah, wisata hidroponik yang lainnya..." (Sabtu, 1 Desember 2018)

Pembahasan mengenai manfaat website yang lebih spesifik disampaikan oleh key informant. Ibu Vera Nofia. Ada banyak manfaat yang dirasakan oleh LSM sejak aktif menggunakan website sebagai media informasi LSM RKBN Pulokambing kepada publik dalam hal ini penerima manfaat yaitu sebagai berikut,

"...Manfaatnya bisa diketahui banyak orang, bisa jualan, bisa berbagi ilmu dan informasi, bisa berbagi cerita, dan bisa menggalang massa..." (Senin, 3 Desember 2018)

Dengan manfaat tersebut, besar harapan dari Ketua LSM RKBN Pulokambing menggunakan website sebagai sarana memberikan informasi kepada publik perihal tentang bidang usaha dalam suatu Lembaga Swadaya Masyarakat (LSM), sehingga LSM tersebut mendapatkan manfaat yang bisa dirasakan guna mengembangkan informasi secara luas, itu semua tidak lepas dari pemanfaatan website yang dilakukan oleh LSM RKBN Pulokambing. Strategi dilakukan guna meningkatkan kualitas serta pemberdayaan masyarakat. Dalam memunculkan Pemanfaatan Website untuk meningkatkan jumlah pengunjung web serta menambah manfaat dari LSM RKBN Pulokambing, 
penulis menanyakan terlebih dahulu sejarah lahirnya website LSM RKBN Pulokambing, dan menurut informan Bu Vera selaku Ketua LSM RKBN Pulokambing menyatakan bahwa :

“...Lahirnya website itu tahun 2016 tanggalnya saya lupa, pengunjung per bulan saya belum ngecek lagi dan nggak tahu juga sih sebenarnya...”(Senin, 3 Desember 2018)

Berdasarkan pernyataan di atas, penulis memahami bahwa website www.pulokambing.com lahir sejak tahun 2016 , dimana LSM menggunakan website sebagai sumber informasi bagi masyarakat karena LSM RKBN Pulokambing saat itu melihat banyak LSM di berbagai bidang sudah memanfaatkan website menurut Bu Vera Nofia Selain apa yang menjadi latar belakang Public Relations, dalam menggunakan website LSM, penulis juga bertanya tentang tujuan dan peran dari website tersebut, key informant menjawab dengan singkat:

“...tujuan dan peran website adalah untuk memudahkan masyarakat mengetahui program pemberdayaan mulai dari koperasi, pengelolaan Bank Sampah, Karya Kreasi, Wisata Edukasi dan Gugus Depan Wilayah...”(Senin, 3 Desember 2018)

Dengan pernyataan tersebut, penulis menyimpulkan bahwa seiring dengan perkembangan teknologi informasi LSM RKBN Pulokambing berharap website mampu menjadi awal dimana klien bisa mengetahui informasi LSM RKBN Pulokambing, dan memberikan pemahaman terkait dengan LSM serta produk dan layanan apa saja yang bisa disediakan oleh LSM.

Dengan teori dan hasil data yang didapatkan penulis selama menjalankan penelitian di LSM RKBN Pulokambing, ada keterkaitan antara sistem komunikasi melalui website yang diharapkan mampu menjaring klien secara luas, tidak saja ke dalam aktivitas pemasaran saja, namun lebih daripada itu, LSM RKBN Pulokambing banyak dikenal publik saat ini, serta mampu meningkatkan visibilitas dalam memberikan informasi kepada pelanggan. Seiring dengan penggunaan website sebagai media promosi, tingkat keberhasilan dari media tersebut dalam meningkatkan jumlah penerima manfaat menjadi buah manis yang dirasakan oleh LSM.

\section{KESIMPULAN}

Berdasarkan hasil penelitian dan pembahasan sebagaimana yang menulis dalam bab sebelumnya mengenai pemanfaatan website www.pulokambing.com sebagai Media LSM RKBN Pulokambing dalam pemberdayaan masyarakat dapat ditarik kesimpulan bahwa pemanfaatan website www.pulokambing.com antara lain dalam pemanfaatan website sebagai media promosi LSM RKBN Pulokambing melakukan penataan konten yang berisi tentang LSM RKBN Pulokambing umumnya terdiri dari pengenalan LSM (Tentang Kita), informasi produk dan jasa yang berguna untuk permintaan produk dan jasa. Website mampu meningkatkan kredibilitas LSM RKBN Pulokambing dimata masyarakat. Kedua dapat menghemat anggaran, maksudnya adalah, LSM RKBN Pulokambing tidak perlu aktif dalam memperkenalkan LSM RKBN Pulokambing dalam kegiatan pemasaran door to door, dengan dibantu website, aktivitas pemasaran serta awareness bisa dijangkau dengan menggunakan website. Ketiga, selalu terhubung dengan klien, maksudnya, ketika ada produk terbaru bisa dilakukan dengan update pada website, jadi klien bisa segera mengetahui. Keempat, dapat menjangkau pasar yang lebih luas. Kelima, meningkatkan jumlah pemberdayaan masyarakat yang bisa dikerjakan oleh LSM RKBN Pulokambing, terutama pengelolaan Bank Sampah yang banyak mengetahui info awal dari website.

\section{DAFTAR PUSTAKA}

\section{Buku}

Agus Salim, 2006, Teori dan Paradigma Penelitian Sosial: Buku Sumber Untuk Penelitian Kualitatif (edisi kedua, Agustus 2006), Tiara

Donni Junni Priansa. 2017 . Perilaku Konsumen dalam Bisnis Kontemporer. Bandung: Alfabeta. Emzir. 2010. Metodologi Penelitian Pendidikan:Kuantitatif dan Kualitatif. Jakarta: Rajawali Pers 
Harsono, 2008. Konsep Dasar Mikro, Meso, dan Makro Pembiayaan Pendidikan.Yogyakarta: Surayajaya Press.

Moleong, Lexy J. 2000. Metodologi Penelitian Kualitatif. Bandung: PT. Remaja Rosdakarya Rahardjo, Susilo \& Gudnanto. (2011). Pemahaman Individu Tekhnik Non Tes. Kudus : Nora Media Enterprise.

Internet

(http://www.apjii.or.id). Diakses 21 November 2018 Pukul 13.35 wib. 